\title{
Age differences in the association of comorbid burden with adverse outcomes in SARS-CoV-2
}

\author{
A. M. O'Hare ${ }^{1,2^{*}}$, K. Berry ${ }^{2}$, V. S. Fan ${ }^{2,3}$, K. Crothers ${ }^{2,3}$, M. C. Eastment ${ }^{4}$, J. A. Dominitz ${ }^{2,5}$, J. A. Shah ${ }^{4}$, P. Green ${ }^{2}$,
} E. Locke ${ }^{2}$ and G. N. loannou ${ }^{2,5}$

\begin{abstract}
Background: Older age and comorbid burden are both associated with adverse outcomes in SARS-CoV-2, but it is not known whether the association between comorbid burden and adverse outcomes differs in older and younger adults.

Objective: To compare the relationship between comorbid burden and adverse outcomes in adults with SARSCoV-2 of different ages (18-64, 65-79 and $\geq 80$ years).

Design, setting, and participants: Observational longitudinal cohort study of 170,528 patients who tested positive for SARS-CoV-2 in the US Department of Veterans Affairs (VA) Health Care System between 2/28/20 and 12/31/2020 who were followed through 01/31/2021.
\end{abstract}

Measurements: Charlson Comorbidity Index (CCI); Incidence of hospitalization, intensive care unit (ICU) admission, mechanical ventilation, and death within 30 days of a positive SARS-CoV-2 test.

Results: The cumulative 30-day incidence of death was $0.8 \%$ in cohort members $<65$ years, $7.1 \%$ in those aged $65-$ 79 years and $20.6 \%$ in those aged $\geq 80$ years. The respective 30 -day incidences of hospitalization were $8.2,21.7$ and $29.5 \%$, of ICU admission were 2.7, 8.6, and $11 \%$ and of mechanical ventilation were 1, 3.9 and 3.2\%. Median CCI (interquartile range) ranged from $0.0(0.0,2.0)$ in the youngest, to $4(2.0,7.0)$ in the oldest age group. The adjusted association of CCl with all outcomes was attenuated at older ages such that the threshold level of CCl above which the risk for each outcome exceeded the reference group (1st quartile) was lower in younger than in older cohort members ( $p<0.001$ for all age group interactions).

Limitations: The $\mathrm{CCl}$ is calculated based on diagnostic codes, which may not provide an accurate assessment of comorbid burden.

Conclusions: Age differences in the distribution and prognostic significance of overall comorbid burden could inform clinical management, vaccination prioritization and population health during the pandemic and argue for more work to understand the role of age and comorbidity in shaping the care of hospitalized patients with SARSCoV-2.

\footnotetext{
* Correspondence: Ann.OHare@va.gov

'Division of Nephrology, Veterans Affairs Puget Sound Healthcare System

and University of Washington, 1660 South Columbian Way, Seattle, WA 98108, USA

${ }^{2}$ Research and Development, Veterans Affairs Puget Sound Health Care System, Seattle, WA, USA

Full list of author information is available at the end of the article
}

(c) The Author(s). 2021 Open Access This article is licensed under a Creative Commons Attribution 4.0 International License, which permits use, sharing, adaptation, distribution and reproduction in any medium or format, as long as you give appropriate credit to the original author(s) and the source, provide a link to the Creative Commons licence, and indicate if changes were made. The images or other third party material in this article are included in the article's Creative Commons licence, unless indicated otherwise in a credit line to the material. If material is not included in the article's Creative Commons licence and your intended use is not permitted by statutory regulation or exceeds the permitted use, you will need to obtain permission directly from the copyright holder. To view a copy of this licence, visit http://creativecommons.org/licenses/by/4.0/ The Creative Commons Public Domain Dedication waiver (http://creativecommons.org/publicdomain/zero/1.0/) applies to the data made available in this article, unless otherwise stated in a credit line to the data. 


\section{Introduction}

Older age is the strongest risk factor for infection with the severe acute respiratory virus syndrome coronavirus-2 (SARS-CoV-2) and older adults have been especially hard-hit during the pandemic [1, 2]. Older adults with SARS-CoV-2 are at increased risk for hospitalization [3-5], critical illness [4, 6-13], prolonged hospitalization $[11,14]$ and mortality $[8,9$, 14-29] compared with their younger counterparts. Because a disproportionate number of hospitalizations and deaths in patients with coronavirus disease 2019 (COVID-19) occur among older adults [30-32], the burden of SARS-CoV-2 has been greatest in countries [33-36] and communities [37] with older populations, and in healthcare facilities [38-40] and health systems serving older adults [41].

However, the prevalence of most comorbid conditions increases with age, which can make it challenging to disentangle the separate effects of age and comorbid burden on outcomes among patients infected with SARSCoV-2. Prior studies have reported an association between Charlson comorbidity score and other measures of comorbid burden with adverse outcomes in SARSCoV-2 after adjustment for age [41-49] and differences across age groups in clinical presentation and outcomes of SARS-CoV-2 [11, 14, 27, 31, 50-53]. There are also reports of age differences in the association of individual comorbid conditions [54-56] with adverse outcomes in infected patients.

While few studies have examined the relationship between age, comorbid burden and adverse outcomes in SARS-CoV-2, available data suggest that the relationship between these factors may be complex. Among the first 11,122 infected patients in Denmark, mortality rates were noted to be extremely low in those $<80$ years old without comorbid conditions but uniformly high in those $\geq 80$ years old regardless of the number of comorbid conditions [57]. Because both age and comorbidity have figured prominently in guidelines for clinical care, vaccination and social distancing during the pandemic, a more detailed understanding of the relationship of age and comorbid burden with a range of adverse outcomes among adults infected with SARS-CoV-2 could inform clinical care, current and future vaccine prioritization and prognostication $[58,59]$ and efforts to estimate disease burden and service needs related to SARS-CoV-2 [33].

The US Department of Veterans Affairs (VA) supports the largest integrated national health care system in the US and provides care for more than six million veterans annually [60]. Because the VA serves both younger and older adults and many veterans have multiple comorbid conditions [61], the system may offer unique insights into the relationship between age, comorbid burden and adverse outcomes in those infected with SARS-CoV-2. We designed a study to evaluate differences across age groups in the association of comorbid burden with a range of adverse outcomes among patients infected with SARS-CoV-2.

\section{Methods}

\section{Data source and study population}

The VA uses a single comprehensive electronic healthcare information network. Data elements from patients' electronic medical records at individual VA facilities are stored centrally in the VA's Corporate Data Warehouse (CDW) which is maintained by the VA Informatics and Computing Infrastructure (VINCI). To support research on the health system impacts of the SARS-CoV-2 pandemic, VA maintains the VA National Surveillance Tool, which includes updated clinical and administrative data extracts for all patients tested for SARS-CoV-2 within the VA, with adjudication of all positive test results [60]. Using this resource, we assembled a cohort of all Veterans who tested positive for SARS-CoV-2 nucleic acid by polymerase chain reaction (PCR) at least once between February 28, 2020 and December 31, 2020 with complete information on test date $(n=170,528)$. The index date for the present study was defined as the date of each patient's earliest positive test result unless this occurred within the first 15 days of a hospital admission, in which case we used the date of hospital admission as the index date. Follow-up for all study outcomes was available through January 31, 2021, allowing for analysis of all outcomes occurring within 30 days after the index date for all cohort members. This study was approved by the Institutional Review Board of the Veterans Affairs Puget Sound Healthcare System which granted a waiver of informed consent as the study was deemed minimal risk because it involved secondary analyses of existing data and could not otherwise have been conducted due to the large size of the cohort and inclusion deceased patients. Our research was conducted in accordance with the Declaration of Helsinki.

\section{Exposure}

The primary exposure was each patient's Charlson Comorbidity Index (CCI) score (categorized by approximate quartile of the distribution within our cohort as $0,1,2-3$ or $\geq 4$ ) based on International Classification of Diseases 10th Revision (ICD-10) codes recorded in VA administrative data on or within 2 years before the index data [62].

\section{Outcomes}

The following outcomes were ascertained for the 30day period following the index data using the VA 
National Surveillance Tool [60]: 1) hospitalization; 2) ICU admission; 3) mechanical ventilation; and 4) death.

\section{Covariates}

All analyses were stratified by patients' age group on the index date (categorized as 18-64, 65-79 and $\geq 80$ years) and adjusted for sex, race (Black, White, Other), Hispanic ethnicity, body mass index body (BMI) (categorized as underweight $\left(<18.5 \mathrm{~kg} / \mathrm{m}^{2}\right)$, normal weight $(18.5-24.9 \mathrm{~kg} /$ $\mathrm{m}^{2}$ ) overweight $\left(25-29.9 \mathrm{~kg} / \mathrm{m}^{2}\right)$, stage 1 obesity $(30-34.9$ $\left.\mathrm{kg} / \mathrm{m}^{2}\right)$ and stages $2 \& 3$ obesity $\left.\left(\geq 35 \mathrm{~kg} / \mathrm{m}^{2}\right)\right)$ and U.S. Federal Region. To account for potential age differences in outcomes within each age group, multivariate analyses were also adjusted for age as a continuous variable.

\section{Statistical analysis}

We used Pearson's $\mathrm{X}^{2}$ test to compare patient characteristics across age groups. We plotted 30-day cumulative rates of mortality, hospitalization, ICU admission, and mechanical ventilation by age using a lowess smoother with a bandwidth of $80 \%$. We used a time-to-event analysis accounting for censoring at the time of death to calculate the crude cumulative 30-day incidence of hospitalization, ICU admission, mechanical ventilation, and death within each age group.

We used Cox proportional hazards models stratified by age group to measure the adjusted association of CCI with hospitalization, ICU admission, mechanical ventilation, and death within the first 30 days after the index date after adjustment for age (as

Table 1 Baseline characteristics of patients with a positive test for SARS-CoV-2 in the VA healthcare system, by age group

\begin{tabular}{|c|c|c|c|c|c|}
\hline Characteristic & $\begin{array}{l}18-64 \text { years } \\
N=99,483\end{array}$ & $\begin{array}{l}65-79 \text { years } \\
N=55,013\end{array}$ & $\begin{array}{l}\geq 80 \text { years } \\
N=26,032\end{array}$ & All patients $N=170,528$ & $P$ value \\
\hline Sex & & & & & $<0.001$ \\
\hline Women, \% & 26.2 & 3.8 & 2.2 & 16.7 & \\
\hline Men, \% & 73.8 & 96.2 & 97.8 & 83.3 & \\
\hline Race & & & & & $<0.001$ \\
\hline White, \% & 51.7 & 72.5 & 77.2 & 60.8 & \\
\hline Black, \% & 23.4 & 18.3 & 12.8 & 20.8 & \\
\hline Other, \% & 3.3 & 2.1 & 1.7 & 2.7 & \\
\hline Missing/Unknown & 21.5 & 7.1 & 8.3 & 15.6 & \\
\hline Ethnicity & & & & & $<0.001$ \\
\hline Non-Hispanic & 69.4 & 89.6 & 89.7 & 77.8 & \\
\hline Hispanic & 11.9 & 6.3 & 5.3 & 9.5 & \\
\hline Missing/Unknown & 18.7 & 4.2 & 5 & 12.7 & \\
\hline Body mass index $\left(\mathrm{kg} / \mathrm{m}^{2}\right)$ & & & & & $<0.001$ \\
\hline$<18.5$ (underweight), \% & 0.4 & 1.2 & 2.7 & 0.9 & \\
\hline 18.5-24.9 (normal weight), \% & 9.9 & 16 & 33.4 & 14.1 & \\
\hline 25.29 .9 (overweight), \% & 25.7 & 34.2 & 37.2 & 29.5 & \\
\hline 30-34.9 (Obese I), \% & 26.2 & 27.6 & 17.1 & 25.8 & \\
\hline$\geq 35$ (Obese II and III), \% & 23.4 & 19.4 & 6.2 & 20.5 & \\
\hline Missing, \% & 14.5 & 1.6 & 3.4 & 9.3 & \\
\hline Charlson Comorbidity Index (median (IQR)) & $0.0(0.0,2.0)$ & $3.0(2.0,6.0)$ & $4.0(2.0,7.0)$ & $1.0(0.0,4.0)$ & $<0.001$ \\
\hline Charlson Comorbidity Index (\%) & & & & & $<0.001$ \\
\hline 0 & 54.6 & 11.2 & 8.8 & 36.3 & \\
\hline 1 & 18.3 & 12 & 9.5 & 15.5 & \\
\hline $2-3$ & 16.4 & 27.5 & 24.2 & 20.7 & \\
\hline$\geq 4$ & 10.7 & 49.3 & 57.5 & 27.6 & \\
\hline Median (IQR) & $18-64$ years & $65-79$ years & $\geq 80$ years & All patients & \\
\hline Hospital LOS & $5(3-9)$ & $7(4-14)$ & $9(5-15)$ & $7(4-13)$ & \\
\hline ICU (LOS) & $4(2-8)$ & $5(3-10)$ & $5(2-9)$ & $5(3-9)$ & \\
\hline
\end{tabular}


a continuous variable), sex, race, Hispanic ethnicity, BMI, and region of residence. We used a two-sided $p$-value threshold of $<0.05$ to assess statistical significance. We confirmed there were no violations of the proportional hazard assumption via visual inspection of log-log graphs. All analyses were stratified by VA medical center. A likelihood ratio test (or $\mathrm{X}^{2}$ test of predicted hazard ratios) was used to evaluate for interaction between age group and CCI in adjusted analyses.

We conducted a supplementary analysis in which we used competing risk models to estimate the 30-day cumulative incidence of hospitalization, ICU admission and mechanical ventilation and to measure the adjusted association of CCI with each of these non-death outcomes [63]. We also repeated the primary analyses using approximate quartiles of the Elixhauser Comorbidity Index (ECI).

All analyses were conducted using Stata/MP Version 15 (StataCorp, LLC. College Station, TX).

\section{Results}

Baseline characteristics

Among the 170,528 patients with a positive test for SARS-CoV-2 during the ascertainment period, 99,483 were aged 18-64, 55,013 were aged 65-79, and 26,032 were aged $\geq 80$ years (Table 1 ). From the youngest to the oldest age group, there were decreases in the percentage of women, patients of Black and Other race, patients of Hispanic ethnicity and overweight patients. The median CCI (interquartile range) ranged from $0.0(0.0,2.0)$ in the youngest to $4(2.0,7.0)$ in the oldest age group. More than half $(54.6 \%)$ of patients in the youngest age group had a CCI of 0 as compared with $8.8 \%$ of those in the oldest age group, while more than half (57.5\%) of those in the oldest age group had a CCI $\geq 4$ as compared with $10.7 \%$ of those in the youngest age group.

\section{Crude 30-day cumulative incidence of hospital admission,} ICU admission, mechanical ventilation, and death by age group

The cumulative incidence of death increased exponentially with increasing age while the incidence of hospitalization, ICU admission, and mechanical ventilation plateaued at older ages, with rates of mechanical ventilation declining beyond the age of 80 (Fig. 1). The 30-day incidence of death increased across age groups and quartiles of CCI for all outcomes except for mechanical ventilation (Fig. 2). In all age groups, the incidence of hospitalization (Fig. 2a), ICU admission (Fig. 2b) and mechanical ventilation (Fig. 2c) were extremely high for those with a CCI in the fourth quartile. The incidence of death increased linearly with CCI quartile for those aged $<65$ and 65-79 years but was extremely high in all quartiles of CCI for those aged $\geq 80$ years (Fig. 2d). Death rates were higher for those aged $\geq 80$ years than for any other age group regardless of CCI. The 30-day incidence of death for those aged $<65$ years with a CCI in the 4th quartile was similar to that for patients aged $65-79$ years with a CCI in the first quartile. Median hospital length of stay ranged from 5 (interquartile range (IQR) 3-9) in the youngest age group to 9 (IQR 5-15) in the oldest age group and median ICU length of stay was 4 (IQR 2-8) in those $<65$ years, 5(IQR 3-10) for those aged $65-79$ and 5 (IQR 2-9) for those aged $\geq 80$ years.

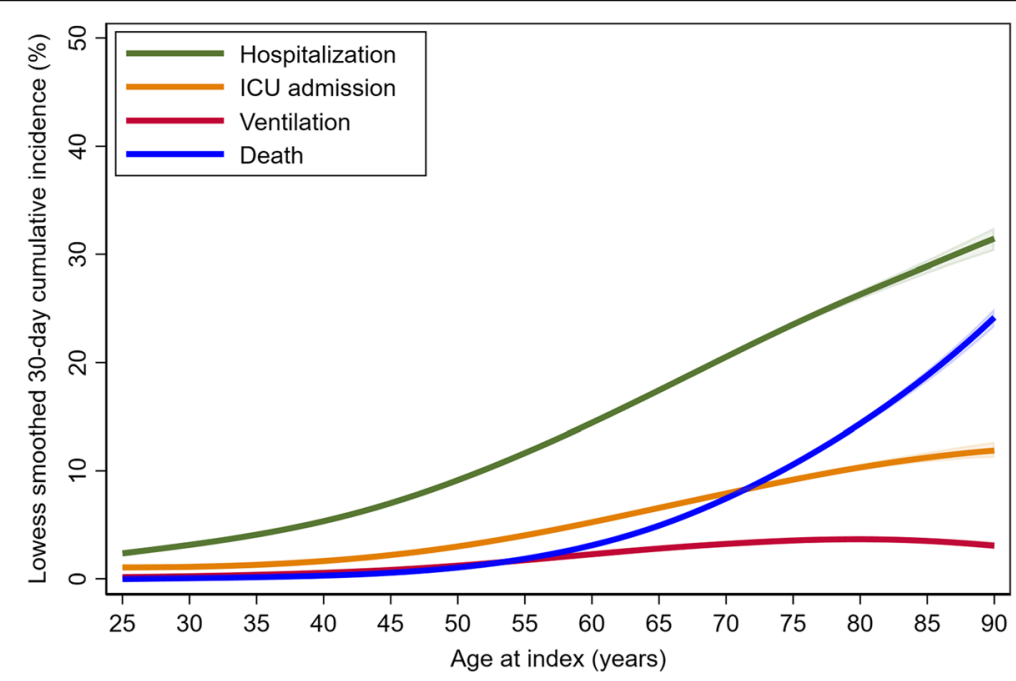

Fig. 1 Lowess smoothed 30-day cumulative rates of hospitalization, ICU admission, mechanical ventilation and death by age at baseline 


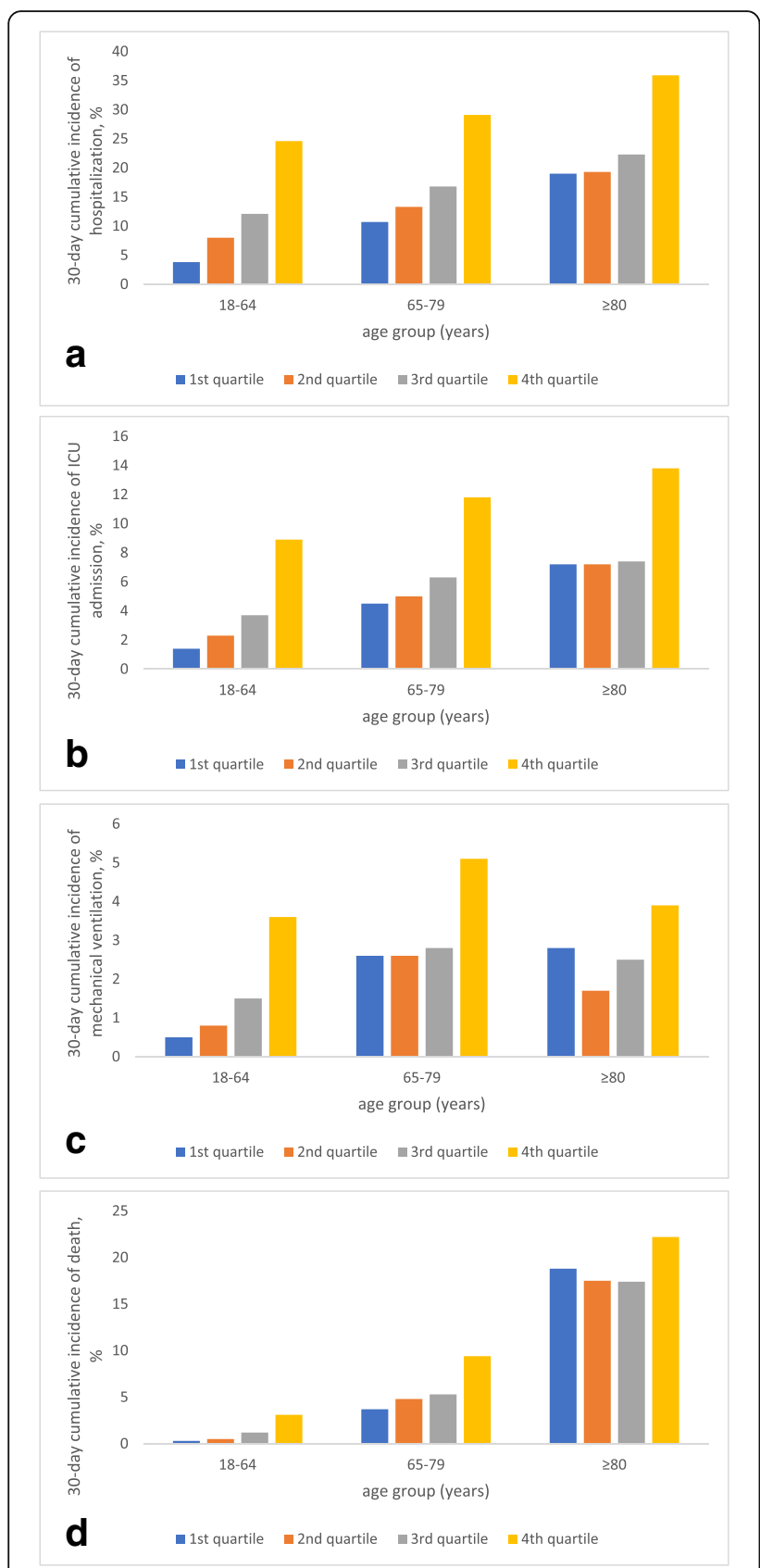

Fig. 2 30-day cumulative incidence of hospitalization (a), ICU admission (b), mechanical ventilation (c) and death (d) by age group

\section{Adjusted analyses of the association of $\mathrm{CCl}$ with} hospitalization, ICU admission, mechanical ventilation and death after stratification by age group

The adjusted association of CCI with all outcomes varied systematically across age groups and was attenuated at older ages ( $p$ values for all age group interactions < 0.001) (Table 2). Among patients $<65$ years, those with a CCI in the 2nd (vs. 1st) quartile (and higher) were at increased risk for hospitalization (adjusted hazard ratio (aHR) 1.43, 95\% confidence interval (CI) 1.33, 1.53) and
ICU admission (aHR 1.25, 95\% CI 1.10, 1.42) and those with a CCI in the 3rd (vs. 1st) quartile (and higher) were at increased risk for mechanical ventilation (aHR 1.41, $95 \%$ CI 1.16, 1.70) and death (aHR 1.74, 95\% CI 1.38, 2.20). Among those aged 65-79years, risk of hospitalization was increased for those with a CCI in the 2nd (vs. 1st) quartile of CCI (aHR 1.19, 95\% CI 1.071.31), risk of ICU admission was increased for those with a CCI in the 3rd (vs. 1st) quartile (aHR 1.33, 95\% CI 1.16-1.53), risk of mechanical ventilation was increased for those with a CCI in the 4th (vs.1st) quartile (aHR 1.69, 95\% CI 1.43-2.01) and risk of death was increased for those with a CCI in the 2nd (vs. 1st) quartile (aHR $1.34,95 \%$ CI 1.12-1.60). However, among patients $\geq 80$ years, only those with CCI in the 4th (vs.1st) quartile of CCI were at increased risk for hospitalization (aHR 1.55, 95\% CI 1.36, 1.78), ICU admission (aHR 1.51, 95\% CI $1.21,1.89$ ) and death (aHR 1.41, 95\% CI 1.22, 1.64). Risk for mechanical ventilation did not vary substantially across quartiles of CCI in this oldest age group and was lowest for those with a CCI in the 2nd quartile (aHR 0.55, 95\% CI 0.33, 0.93 (Table 2).

Results for non-death outcomes were similar when we used a competing risk model (Additional file: Table 1). The results of a sensitivity analysis examining associations of ECI with study outcomes after stratification by age were similar to the primary analysis (Additional file: Table 2).

\section{Discussion}

Among VA patients who tested positive for SARSCoV-2 during the first 10 months of the pandemic, there were marked differences across age groups in the prevalence and prognostic significance of comorbid burden. Associations of comorbid burden with adverse outcomes were generally attenuated at older ages leading to systematic differences across age groups in the threshold level of the CCI (and ECI) associated with an increased risk for adverse outcomes. In cohort members < 65 years and 65-79years, risk for most outcomes was increased for patients with a CCI in the second or third quartile (CCI of 1 or $2-3$, respectively) or higher. On the other hand, among those aged $\geq 80$ years, only a CCI in the 4 th quartile $(\mathrm{CCI} \geq 4)$ was associated with an increased risk for hospitalization, ICU admission and death and risk of mechanical ventilation did not vary greatly with CCI.

The disproportionate number of deaths occurring among older adults is a distinguishing feature of the SARS-CoV-2 pandemic as compared with prior influenza pandemics [32]. The very steep age gradient in risks of death and hospitalization and strong association of comorbid burden with adverse outcomes among younger and middle aged members of our cohort generally 
Table 2 Adjusted association of Charlson Comorbidity Index with hospitalization, ICU admission, mechanical ventilation and death, stratified by age group

\begin{tabular}{|c|c|c|c|c|c|}
\hline & $18-64$ years $N=99,483$ & $65-79$ years $N=55,013$ & $\geq 80$ years $N=26,032$ & $\begin{array}{l}\text { All patients } N=170 \text {, } \\
528\end{array}$ & \\
\hline & $\begin{array}{l}\text { Adjusted }{ }^{\mathrm{ab}} \text { hazard } \\
\text { ratio ( } 95 \% \text { confidence } \\
\text { intervals) }\end{array}$ & $\begin{array}{l}\text { Adjusted }{ }^{\mathrm{ab}} \text { hazard } \\
\text { ratio ( } 95 \% \text { confidence } \\
\text { intervals) }\end{array}$ & $\begin{array}{l}\text { Adjusted }^{\mathrm{ab}} \text { hazard } \\
\text { ratio ( } 95 \% \text { confidence } \\
\text { intervals) }\end{array}$ & $\begin{array}{l}\text { Adjusted }{ }^{\mathrm{ab}} \text { hazard } \\
\text { ratio ( } 95 \% \text { confidence } \\
\text { intervals) }\end{array}$ & $\begin{array}{l}\text { P for interaction } \\
\text { with age group }\end{array}$ \\
\hline Hospitalization & & & & & \\
\hline $\begin{array}{l}\text { Number of } \\
\text { hospitalizations }\end{array}$ & 8,110 & 11,907 & 4,676 & 24,693 & \\
\hline $\begin{array}{l}\text { 30-day cumulative } \\
\text { incidence of } \\
\text { hospitalization (per } 100 \\
\text { patients) }\end{array}$ & 8.2 & 21.7 & 29.5 & 14.5 & $<0.001^{* * *}$ \\
\hline $\begin{array}{l}\text { Median length of stay } \\
(\text { (IQR), days }\end{array}$ & $4(2-8)$ & $6(3-13)$ & $8(4-15)$ & $6(3-12)$ & \\
\hline Charlson Comorbidity Index & & & & & $<0.001^{* * *}$ \\
\hline 0 & 1 & 1 & 1 & 1 & \\
\hline 1 & $1.40(1.31-1.51)^{* * *}$ & $1.19(1.07-1.31)^{* *}$ & $0.91(0.77-1.08)$ & $1.37(1.29-1.44)^{* * *}$ & \\
\hline $2-3$ & $1.86(1.73-1.99)^{* * *}$ & $1.48(1.36-1.62)^{* * *}$ & $1.01(0.88-1.17)$ & $1.75(1.66-1.84)^{* * *}$ & \\
\hline$\geq 4$ & $3.35(3.13-3.58)^{* * *}$ & $2.51(2.31-2.73)^{* * *}$ & $1.55(1.36-1.78)^{* * *}$ & $2.91(2.77-3.05)^{* * *}$ & \\
\hline ICU admission & & & & & \\
\hline $\begin{array}{l}\text { Median Length of stay } \\
\text { (IQR), days }\end{array}$ & $4(1-7)$ & $4(2-10)$ & $4(2-8)$ & $4(2-9)$ & \\
\hline $\begin{array}{l}\text { Number of ICU } \\
\text { admissions }\end{array}$ & 2,705 & 4,709 & 1,712 & 9,126 & $<0.001^{* * *}$ \\
\hline $\begin{array}{l}\text { 30-day cumulative } \\
\text { incidence of ICU } \\
\text { admission (per } 100 \\
\text { patients) }\end{array}$ & 2.7 & 8.6 & 11 & 5.4 & \\
\hline Charlson Comorbidity Index & & & & & $<0.001^{* * *}$ \\
\hline 0 & 1 & 1 & 1 & 1 & \\
\hline 1 & $1.25(1.10-1.42)^{* * *}$ & $1.11(0.94-1.30)$ & $0.92(0.70-1.23)$ & $1.25(1.14-1.37)^{* * *}$ & \\
\hline $2-3$ & $1.70(1.51-1.92)^{* * *}$ & $1.33(1.16-1.53)^{* * *}$ & $0.91(0.71-1.16)$ & $1.60(1.47-1.74)^{* * *}$ & \\
\hline$\geq 4$ & $3.43(3.05-3.85)^{* * *}$ & $2.36(2.08-2.69)^{* * *}$ & $1.51(1.21-1.89)^{* * *}$ & $2.88(2.66-3.12)^{* * *}$ & \\
\hline Mechanical ventilation & & & & & $<0.001^{* * *}$ \\
\hline $\begin{array}{l}\text { Number receiving } \\
\text { mechanical ventilation }\end{array}$ & 1,017 & 2,109 & 490 & 3,616 & \\
\hline $\begin{array}{l}\text { 30-day incidence of } \\
\text { mechanical ventilation } \\
\text { (per } 100 \text { patients) }\end{array}$ & 1 & 3.9 & 3.2 & 2.1 & \\
\hline Charlson Comorbidity Index & & & & & $<0.001^{* * *}$ \\
\hline 0 & 1 & 1 & 1 & 1 & \\
\hline 1 & $0.91(0.73-1.13)$ & $0.97(0.78-1.20)$ & $0.55(0.33-0.93)^{*}$ & $1.06(0.92-1.23)$ & \\
\hline $2-3$ & $1.41(1.16-1.70)^{* * *}$ & $1.00(0.83-1.21)$ & $0.76(0.51-1.13)$ & $1.44(1.27-1.64)^{* * *}$ & \\
\hline$\geq 4$ & $2.72(2.26-3.26)^{* * *}$ & $1.69(1.43-2.01)^{* * *}$ & $1.03(0.71-1.48)$ & $2.43(2.16-2.74)^{* * *}$ & \\
\hline Death & & & & & $<0.001^{* * *}$ \\
\hline Number of deaths & 770 & 3,897 & 3,255 & 7,922 & \\
\hline $\begin{array}{l}\text { 30-day cumulative } \\
\text { incidence of death (per } \\
100 \text { patients) }\end{array}$ & 0.8 & 7.1 & 20.3 & 4.6 & \\
\hline
\end{tabular}


Table 2 Adjusted association of Charlson Comorbidity Index with hospitalization, ICU admission, mechanical ventilation and death, stratified by age group (Continued)

\begin{tabular}{|c|c|c|c|c|c|}
\hline & $18-64$ years $N=99,483$ & $65-79$ years $N=55,013$ & $\geq 80$ years $N=26,032$ & $\begin{array}{l}\text { All patients } N=170 \text {, } \\
528\end{array}$ & \\
\hline & $\begin{array}{l}\text { Adjusted }^{\mathrm{ab}} \text { hazard } \\
\text { ratio ( } 95 \% \text { confidence } \\
\text { intervals) }\end{array}$ & $\begin{array}{l}\text { Adjusted }{ }^{\mathrm{ab}} \text { hazard } \\
\text { ratio ( } 95 \% \text { confidence } \\
\text { intervals) }\end{array}$ & $\begin{array}{l}\text { Adjusted }{ }^{\mathrm{ab}} \text { hazard } \\
\text { ratio ( } 95 \% \text { confidence } \\
\text { intervals) }\end{array}$ & $\begin{array}{l}\text { Adjusted }{ }^{\mathrm{ab}} \text { hazard } \\
\text { ratio ( } 95 \% \text { confidence } \\
\text { intervals) }\end{array}$ & $\begin{array}{l}\text { P for interaction } \\
\text { with age group }\end{array}$ \\
\hline Charlson Comorbidity Index & & & & & $<0.001^{* * *}$ \\
\hline 0 & 1 & 1 & 1 & 1 & \\
\hline 1 & $0.98(0.75-1.29)$ & $1.34(1.12-1.60)^{* *}$ & $1.05(0.88-1.26)$ & $1.29(1.15-1.44)^{* * *}$ & \\
\hline $2-3$ & $1.74(1.38-2.20)^{* * *}$ & $1.45(1.25-1.70)^{* * *}$ & $1.08(0.92-1.27)$ & $1.53(1.38-1.69)^{* * *}$ & \\
\hline$\geq 4$ & $3.26(2.61-4.08)^{* * *}$ & $2.48(2.14-2.86)^{* * *}$ & $1.41(1.22-1.64)^{* * *}$ & $2.35(2.14-2.59)^{* * *}$ & \\
\hline
\end{tabular}

${ }^{a}$ Adjusted for Federal Emergency Management Agency region: 1 (Connecticut, Massachusetts, Maine, New Hampshire, Rhode Island, Vermont), 2 (New Jersey, New York, Puerto Rico), 3 (District of Columbia, Delaware, Maryland, Pennsylvania, Virginia, West Virginia), 4 (Alabama, Florida, Georgia, Kentucky, Mississippi, North Carolina, South Carolina, Tennessee), 5 (Illinois, Indiana, Michigan, Minnesota, Ohio, Wisconsin), 6 (Arkansas, Louisiana, New Mexico, Oklahoma, Texas), 7 (lowa, Kansas, Missouri, Nebraska), 8 (Colorado, Montana, North Dakota, South Dakota, Utah, Wyoming), 9 (Arizona, California, Guam, Hawaii, Nevada), 10 (Alaska, Idaho, Oregon, Washington) and all characteristics listed in Table 1 with the exception that age was modeled as a continuous variable.

${ }^{\mathrm{b}}$ Stratified by station.

${ }^{*} P<0.05,{ }^{* *} P<0.01,{ }^{* * *} P<0.001$

supports the US Centers for Disease Controlrecommended approach to vaccine prioritization based on age and the presence of comorbid conditions among younger and middle-aged (i.e. < 65 years) adults [64]. However, as we and others have argued elsewhere, there may be opportunities to refine ongoing vaccine prioritization strategies by accounting for the presence of sizeable differences within age groups in risk for adverse outcomes [65-67].

Consistent with the crude mortality rates reported by Reilev et al. for the first 11,122 infected patients in Denmark, risk of death was extremely high for the oldest members of our cohort regardless of CCI [57]. However, there were substantial differences in the relative risk for all adverse outcomes across quartiles of comorbid burden in younger age groups, including those aged 65-79 years. Further, rates of hospitalization, ICU admission and mechanical ventilation for patients with a CCI in the fourth quartile were extremely high regardless of age. Prioritization for vaccination and risk stratification based on comorbid burden may be especially impactful for those aged 65-79years given that their absolute mortality and hospitalization rates substantially exceed those aged $<65$ years. Collectively, these findings suggest there may be opportunities to refine ongoing vaccine allocation strategies to improve risk stratification within this relatively large high-risk group.

While prior studies have described strong associations of CCI and other measures of comorbid burden with adverse outcomes in patients infected with SARS-CoV-2 after adjusting for age [41-48], none to our knowledge have evaluated the adjusted association of comorbid burden with adverse outcomes after stratification by age group. However, our major finding of systematic differences across age groups in the strength and magnitude of the association of comorbid burden with hospitalization, death and ICU admission among patients with SARS-CoV-2 seems consistent with other work describing age differences in the association of individual comorbid conditions [54-56] with adverse outcomes among infected patients. An attenuation of the association of comorbid burden with adverse outcomes in patients with SARS-CoV-2 at older ages also resonates with earlier work demonstrating that in older adults, the presence or absence of particular comorbid conditions and/or abnormalities in specific disease markers often have less prognostic significance than more global measures of functional status and frailty that are not necessarily tied to the presence or severity of specific underlying disease processes [68-70]. Our findings may also suggest the need for alternative approaches to risk stratification within the oldest age group, perhaps based on non-disease-specific measures such as frailty and functional status (71) or different threshold levels of comorbid burden.

Consistent with earlier studies conducted in a range of different populations infected with SARS-CoV-2 [8, 9, 14-29, 71], the age gradient for crude mortality was extremely steep and mortality rates increased exponentially while slopes for non-death outcomes plateaued at older ages. Age-related increases in rates of ICU admission and mechanical ventilation among members of our cohort were much less steep than those for mortality and hospitalization. Of particular note, crude rates of mechanical ventilation peaked among patients in their late 70's and declined at older ages and the association of CCI with mechanical ventilation was substantially attenuated among those aged 65-79years and extinguished in the oldest age group. These findings support the possibility that clinical management of hospitalized patients 
infected with SARS-CoV-2 might vary depending on the patient's age and comorbid burden [72]. Collectively, our work argues for studies to understand the impact of age and comorbidity on real-world care practices for patients infected with SARS-CoV-2.

Limitations of our study include first, that our results may not be generalizable to other populations, particularly non-veteran populations and those that include a higher percentage of women. Second, ascertainment of comorbidity was limited to information included in ICD-10 codes which may not fully capture the severity of individual comorbid conditions or comorbid disease burden. Third, we only had information on hospitalizations occurring within the VA or under VA Community Care, thus our results may underestimate rates of nondeath outcomes among cohort members. Fourth, due to selective testing for SARS-CoV-2 within our health system, our results may not be generalizable to infected Veterans not tested within the VA and may be subject to bias based on age and comorbidity. Finally, our analyses are adjusted for a limited number of measured patient characteristics and may reflect confounding by unmeasured characteristics.

In conclusion, while prior studies have demonstrated strong associations between older age and comorbid burden with the severe manifestations of COVID-19, none have rigorously evaluated for age differences in the strength and magnitude of the association of comorbid burden with a range of adverse outcomes. Our finding of systematic differences across age groups in the distribution and prognostic significance of comorbid burden among patients infected with SARS-CoV-2 could help to inform clinical care, ongoing vaccine prioritization and prognostication. Age differences in outcomes for hospitalized patients with SARS-CoV-2 also argue for more work to understand the role of age and comorbid burden in shaping clinical care and decision-making.

\section{Supplementary Information}

The online version contains supplementary material available at https://doi. org/10.1186/s12877-021-02340-5.

\section{Additional file 1}

\section{Acknowledgements}

We acknowledge the VA Office of Research and Development's work to develop and support the VA COVID-19 National Surveillance Tool.

\section{Authors' contributions}

All authors approved the final version of the manuscript. AO: Study concept and design $(A O, G l, K B)$, Interpretation of results $(A O, K B, G l, J S, K C, M E$, JD, $V F)$, analysis of data (KB, $P G)$, drafting of manuscript ( $A O$ and $K B$ ),

Administrative support and approvals (EL), critical revision of manuscript ( $A O$, $G I, K B, J S, K C, M E, J D, V F, P G, E L)$.

\section{Funding}

The study was supported by VA CSR\&D grant COVID19-8900-11 to GNI.

\section{Availability of data and materials}

Our data were obtained under data use agreement and cannot be shared beyond the study team members authorized to access the data. The data sources we used are accessible to other VA researchers for approved projects: https://www.hsrd.research.va.gov/for_researchers/cyber_seminars/ archives/video_archive.cfm?SessionlD=3834

\section{Declarations}

Ethics approval and consent to participate

The study was approved the Institutional Review Board at the VA Puget Sound Health Care System.

Consent for publication

Not applicable.

\section{Competing interests}

None.

\section{Author details}

${ }^{1}$ Division of Nephrology, Veterans Affairs Puget Sound Healthcare System and University of Washington, 1660 South Columbian Way, Seattle, WA 98108, USA. ${ }^{2}$ Research and Development, Veterans Affairs Puget Sound Health Care System, Seattle, WA, USA. ${ }^{3}$ Division of Pulmonary and Critical Care, Veterans Affairs Puget Sound Healthcare System and University of Washington, Seattle, WA, USA. ${ }^{4}$ Division of Allergy and Infectious Disease, Veterans Affairs Puget Sound Healthcare System and University of Washington, Seattle, WA, USA. ${ }^{5}$ Division of Gastroenterology, Veterans Affairs Puget Sound Healthcare System and University of Washington, Seattle, WA, USA.

Received: 27 October 2020 Accepted: 6 June 2021

Published online: 06 July 2021

\section{References}

1. Pollan M, Perez-Gomez B, Pastor-Barriuso R, Oteo J, Hernan MA, PerezOlmeda M, et al. Prevalence of SARS-CoV-2 in Spain (ENE-COVID): a nationwide, population-based seroepidemiological study. Lancet. 2020; 396(10250):535-44. https://doi.org/10.1016/S0140-6736(20)31483-5.

2. Powell T, Bellin E, Ehrlich AR. Older adults and Covid-19: the Most vulnerable, the hardest hit. Hast Cent Rep. 2020;50(3):61-3. https://doi.org/1 $0.1002 /$ hast.1136.

3. Price-Haywood EG, Burton J, Fort D, Seoane L. Hospitalization and mortality among black patients and White patients with Covid-19. N Engl J Med. 2020;382(26):2534-43. https://doi.org/10.1056/NEJMsa2011686.

4. Petrilli CM, Jones SA, Yang J, Rajagopalan H, O'Donnell L, Chernyak Y, et al. Factors associated with hospital admission and critical illness among 5279 people with coronavirus disease 2019 in new York City: prospective cohort study. BMJ. 2020:369:m1966.

5. Gianfrancesco M, Hyrich KL, Al-Adely S, Carmona L, Danila Ml, Gossec L, et al. Characteristics associated with hospitalisation for COVID-19 in people with rheumatic disease: data from the COVID-19 global rheumatology Alliance physician-reported registry. Ann Rheum Dis. 2020;79(7):859-66. https://doi.org/10.1136/annrheumdis-2020-217871.

6. Tian J, Yuan X, Xiao J, Zhong Q, Yang C, Liu B, et al. Clinical characteristics and risk factors associated with COVID-19 disease severity in patients with cancer in Wuhan, China: a multicentre, retrospective, cohort study. Lancet Oncol. 2020;21(7):893-903. https://doi.org/10.1016/S1470-2045(20)30309-0.

7. Liang W, Liang H, Ou L, Chen B, Chen A, Li C, et al. Development and validation of a clinical risk score to predict the occurrence of critical illness in hospitalized patients with COVID-19. JAMA Intern Med. 2020;180(8):10819. https://doi.org/10.1001/jamainternmed.2020.2033.

8. Suleyman G, Fadel RA, Malette KM, Hammond C, Abdulla H, Entz A, et al. Clinical characteristics and morbidity associated with coronavirus disease 2019 in a series of patients in metropolitan Detroit. JAMA Netw Open. 2020; 3(6):e2012270. https://doi.org/10.1001/jamanetworkopen.2020.12270.

9. Wu C, Chen X, Cai Y, Xia J, Zhou X, Xu S, et al. Risk factors associated with acute respiratory distress syndrome and death in patients with coronavirus disease 2019 pneumonia in Wuhan, China. JAMA Intern Med. 2020;180(7): 934-43. https://doi.org/10.1001/jamainternmed.2020.0994. 
10. Wang D, Hu B, Hu C, Zhu F, Liu X, Zhang J, et al. Clinical Characteristics of 138 Hospitalized Patients With 2019 Novel coronavirus-infected pneumonia in Wuhan, China. JAMA. 2020;17;323(11):1061-9. https://doi.org/10.1001/ja ma.2020.1585.

11. Gold JAW, Wong KK, Szablewski CM, Patel PR, Rossow J, da Silva J, et al. Characteristics and clinical outcomes of adult patients hospitalized with COVID-19 - Georgia, march 2020. MMWR Morb Mortal Wkly Rep. 2020; 69(18):545-50. https://doi.org/10.15585/mmwr.mm6918e1.

12. Kim L, Garg S, O'Halloran A, Whitaker M, Pham H, Anderson EJ, et al. Risk Factors for Intensive Care Unit Admission and In-hospital Mortality among Hospitalized Adults Identified through the U.S. Coronavirus Disease 2019 (COVID-19)-Associated Hospitalization Surveillance Network (COVID-NET). Clin Infect Dis. 2021;72(9):e206-14. https://doi.org/10.1093/cid/ciaa1012.

13. Jain V, Yuan JM. Predictive symptoms and comorbidities for severe COVID19 and intensive care unit admission: a systematic review and meta-analysis. Int J Public Health. 2020;65(5):533-46. https://doi.org/10.1007/s00038-02001390-7.

14. Docherty AB, Harrison EM, Green CA, Hardwick HE, Pius R, Norman L, et al. Features of 20133 UK patients in hospital with covid-19 using the ISARIC WHO clinical characterisation protocol: prospective observational cohort study. BMJ. 2020;369:m1985.

15. Yang X, Yu Y, Xu J, Shu H, Xia J, Liu H, et al. Clinical course and outcomes of critically ill patients with SARS-CoV-2 pneumonia in Wuhan, China: a singlecentered, retrospective, observational study. Lancet Respir Med. 2020;8(5): 475-81. https://doi.org/10.1016/S2213-2600(20)30079-5.

16. Zhou F, Yu T, Du R, Fan G, Liu Y, Liu Z, et al. Clinical course and risk factors for mortality of adult inpatients with COVID-19 in Wuhan, China: a retrospective cohort study. Lancet. 2020;395(10229):1054-62. https://doi. org/10.1016/50140-6736(20)30566-3.

17. Cummings MJ, Baldwin MR, Abrams D, Jacobson SD, Meyer BJ, Balough EM, et al. Epidemiology, clinical course, and outcomes of critically ill adults with COVID-19 in new York City: a prospective cohort study. Lancet. 2020; 395(10239):1763-70. https://doi.org/10.1016/S0140-6736(20)31189-2.

18. Grasselli G, Zanella A. Critically ill patients with COVD-19 in new York City. Lancet. 2020;395(10239):1740-1. https://doi.org/10.1016/S0140-6736(20)31190-9.

19. Garg S, Kim L, Whitaker M, O'Halloran A, Cummings C, Holstein R, et al. Hospitalization rates and characteristics of patients hospitalized with laboratory-confirmed coronavirus disease 2019 - COVID-NET, 14 states, march 1-30, 2020. MMWR Morb Mortal Wkly Rep. 2020;69(15):458-64. https://doi.org/10.15585/mmwr.mm6915e3.

20. Kuderer NM, Choueiri TK, Shah DP, Shyr Y, Rubinstein SM, Rivera DR, et al. Clinical impact of COVID-19 on patients with cancer (CCC19): a cohort study. Lancet. 2020;395(10241):1907-18. https://doi.org/10.1016/S0140-673 6(20)31187-9.

21. Lee LYW, Cazier JB, Starkey T, Turnbull CD, Team UKCCMP, Kerr R, et al. COVID-19 mortality in patients with cancer on chemotherapy or other anticancer treatments: a prospective cohort study. Lancet. 2020;395(10241): 1919-26. https://doi.org/10.1016/S0140-6736(20)31173-9.

22. Cariou B, Hadjadj S, Wargny M, Pichelin M, Al-Salameh A, Allix I, et al. Phenotypic characteristics and prognosis of inpatients with COVID-19 and diabetes: the CORONADO study. Diabetologia. 2020;63(8):1500-15. https:// doi.org/10.1007/s00125-020-05180-x. Epub 2020 May 29.

23. Baqui P, Bica I, Marra V, Ercole A, van der Schaar M. Ethnic and regional variations in hospital mortality from COVID-19 in Brazil: a cross-sectional observational study. Lancet Glob Health. 2020;8(8):e1018-26. https://doi. org/10.1016/S2214-109X(20)30285-0.

24. Richardson S, Hirsch JS, Narasimhan M, Crawford JM, McGinn T, Davidson $\mathrm{KW}$, et al. Presenting characteristics, comorbidities, and outcomes among 5700 patients hospitalized with COVID-19 in the new York City area. JAMA. 2020;323(20):2052-9. https://doi.org/10.1001/jama.2020.6775.

25. Gupta S, Hayek SS, Wang W, Chan L, Mathews KS, Melamed ML, et al. Factors associated with death in critically ill patients with coronavirus disease 2019 in the US. JAMA Intern Med. 2020;180(11):1436-47. https://doi. org/10.1001/jamainternmed.2020.3596.

26. Williamson EJ, Walker AJ, Bhaskaran K, Bacon S, Bates C, Morton CE, et al. OpenSAFELY: factors associated with COVID-19 death in 17 million patients. Nature. 2020;584(7821):430-6. https://doi.org/10.1038/s41586-020-2521-4.

27. Martin-Sanchez FJ, Del Toro E, Cardassay E, Valls Carbo A, Cuesta F, Vigara $M$, et al. Clinical presentation and outcome across age categories among patients with COVID-19 admitted to a Spanish emergency department. Eur Geriatr Med. 2020;11(5):829-41. https://doi.org/10.1007/s41999-020-00359-2.
28. Wynants L, Van Calster B, Collins GS, Riley RD, Heinze G, Schuit E, et al. Prediction models for diagnosis and prognosis of covid-19 infection: systematic review and critical appraisal. BMJ. 2020;369:m1328.

29. Incerti D, Rizzo S, Li X, Lindsay L, Yau V, Keebler D, et al. Prognostic model to identify and quantify risk factors for mortality among hospitalised patients with COVID-19 in the USA. BMJ Open. 2021;11(4):e047121. https:// doi.org/10.1136/bmjopen-2020-047121.

30. Chen T, Wu D, Chen H, Yan W, Yang D, Chen G, et al. Clinical characteristics of 113 deceased patients with coronavirus disease 2019: retrospective study. BMJ. 2020;368:m1091.

31. Team CC-R. Severe outcomes among patients with coronavirus disease 2019 (COVID-19) - United States, February 12-march 16, 2020. MMWR Morb Mortal Wkly Rep. 2020;69(12):343-6.

32. Petersen E, Koopmans M, Go U, Hamer DH, Petrosillo N, Castelli F, et al. Comparing SARS-CoV-2 with SARS-CoV and influenza pandemics. Lancet Infect Dis. 2020;20(9):e238-44. https://doi.org/10.1016/S1473-3099(20)30484-9.

33. Clark A, Jit M, Warren-Gash C, Guthrie B, Wang HHX, Mercer SW, et al. Global, regional, and national estimates of the population at increased risk of severe COVID-19 due to underlying health conditions in 2020: a modelling study. Lancet Glob Health. 2020;8(8):e1003-17. https://doi.org/1 0.1016/S2214-109X(20)30264-3.

34. Onder G, Rezza G, Brusaferro S. Case-fatality rate and characteristics of patients dying in relation to COVID-19 in Italy. JAMA. 2020. https://doi.org/1 0.1001/jama.2020.4683.

35. Sudharsanan N, Didzun O, Barnighausen T, Geldsetzer P. The contribution of the age distribution of cases to COVID-19 case fatality across countries: a 9country demographic study. Ann Intern Med. 2020;173(9):714-20. https:// doi.org/10.7326/M20-2973.

36. Fisman DN, Greer AL, Tuite AR. Age is just a number: a critically important number for COVID-19 case fatality. Ann Intern Med. 2020;173(9):762-3. https://doi.org/10.7326/M20-4048.

37. Millett GA, Jones AT, Benkeser D, Baral S, Mercer L, Beyrer C, et al. Assessing differential impacts of COVID-19 on black communities. Ann Epidemiol. 2020:47:37-44. https://doi.org/10.1016/j.annepidem.2020.05.003.

38. McMichael TM, Currie DW, Clark S, Pogosjans S, Kay M, Schwartz NG, et al. Epidemiology of Covid-19 in a long-term Care Facility in King County, Washington. N Engl J Med. 2020;382(21):2005-11. https://doi.org/10.1056/NEJMoa2005412.

39. Graham NSN, Junghans C, Downes R, Sendall C, Lai H, McKirdy A, et al. SARS-CoV-2 infection, clinical features and outcome of COVID-19 in United Kingdom nursing homes. J Infect. 2020;81(3):411-9. https://doi.org/10.1016/j. jinf.2020.05.073. Epub 2020 June 343.

40. Panagiotou OA, Kosar CM, White EM, Bantis LE, Yang X, Santostefano CM, et al. Risk factors associated with all-cause 30-day mortality in nursing home residents with COVID-19. JAMA Intern Med. 2021;181(4):439-48. https://doi. org/10.1001/jamainternmed.2020.7968.

41. Ioannou GN, Locke E, Green P, Berry K, O'Hare AM, Shah JA, et al. Risk factors for hospitalization, mechanical ventilation, or death among 10131 US veterans with SARS-CoV-2 infection. JAMA Netw Open. 2020;3(9):e2022310. https://doi.org/10.1001/jamanetworkopen.2020.22310.

42. Christensen DM, Strange JE, Gislason G, Torp-Pedersen C, Gerds T, Fosbol E, et al. Charlson comorbidity index score and risk of severe outcome and death in Danish COVID-19 patients. J Gen Intern Med. 2020;35(9):2801-3. https://doi.org/10.1007/s11606-020-05991-z.

43. laccarino G, Grassi G, Borghi C, Ferri C, Salvetti M, Volpe M, et al. Age and Multimorbidity Predict Death Among COVID-19 Patients: Results of the SARS-RAS Study of the Italian Society of Hypertension. Hypertension. 2020; 76(2):366-72. https://doi.org/10.1161/HYPERTENSIONAHA.120.15324. Epub 2020 Jun 22. PMID: 32564693.

44. Imam Z, Odish F, Armstrong J, Elassar H, Dokter J, Langnas E, et al. Independent correlates of hospitalization in 2040 patients with COVID-19 at a large hospital system in Michigan, United States. J Gen Intern Med. 2020; 35(8):2516-7. https://doi.org/10.1007/s11606-020-05937-5.

45. Munoz P, Galar A, Catalan P, Valerio M, Aldamiz-Echevarria T, Colliga C, et al. The first 100 cases of COVID-19 in a Hospital in Madrid with a 2-month follow-up. Rev Esp Quimioter. 2020;33(5):369-78. https://doi.org/10.37201/ req/072.2020.

46. Zhou W, Qin X, Hu X, Lu Y, Pan J. Prognosis models for severe and critical COVID-19 based on the Charlson and Elixhauser comorbidity indices. Int J Med Sci. 2020;17(15):2257-63. https://doi.org/10.7150/ijms.50007.

47. Bhargava A, Sharma M, Riederer K, Fukushima EA, Szpunar SM, Saravolatz L. Risk factors for in-hospital mortality from COVID-19 infection among black 
patients - an Urban Center experience. Clin Infect Dis. 2020. https://doi. org/10.1093/cid/ciaa1468.

48. Rodilla E, Saura A, Jimenez I, Mendizabal A, Pineda-Cantero A, LorenzoHernandez E, et al. Association of Hypertension with All-Cause Mortality among Hospitalized Patients with COVID-19. J Clin Med. 2020;9(10):3136. https://doi.org/10.3390/jcm9103136.

49. Varol Y, Hakoglu B, Kadri Cirak A, Polat G, Komurcuoglu B, Akkol B, et al. The impact of charlson comorbidity index on mortality from SARS-CoV-2 virus infection and a novel COVID-19 mortality index: CoLACD. Int J Clin Pract. 2021;75(4):e13858. https://doi.org/10.1111/ijcp.13858.

50. Mercante G, Ferreli F, De Virgilio A, Gaino F, Di Bari M, Colombo G, et al. Prevalence of Taste and Smell Dysfunction in Coronavirus Disease 2019. JAMA Otolaryngol Head Neck Surg. 2020;146(8):723-8. https://doi.org/10.1 001/jamaoto.2020.1155. PMID: 32556070.

51. Myers LC, Parodi SM, Escobar GJ, Liu VX. Characteristics of hospitalized adults with COVID-19 in an integrated health care system in California. JAMA. 2020;323(21):2195-8. https://doi.org/10.1001/jama.2020.7202.

52. Palmieri L, Vanacore N, Donfrancesco C, Lo Noce C, Canevelli M, Punzo O, et al. Clinical characteristics of hospitalized individuals dying with COVID-19 by age Group in Italy. J Gerontol A Biol Sci Med Sci. 2020;75(9):1796-800. https://doi.org/10.1093/gerona/glaa146.

53. Grasselli G, Pesenti A, Cecconi M. Critical care utilization for the COVID-19 outbreak in Lombardy, Italy: early experience and forecast during an emergency response. JAMA. 2020;323(16):1545-6. https://doi.org/10.1001/ja ma.2020.4031.

54. Harrison SL, Fazio-Eynullayeva E, Lane DA, Underhill P, Lip GYH. Comorbidities associated with mortality in 31,461 adults with COVID-19 in the United States: a federated electronic medical record analysis. PLoS Med. 2020;17(9):e1003321. https://doi.org/10.1371/journal.pmed.1003321.

55. Tartof SY, Qian L, Hong V, Wei R, Nadjafi RF, Fischer H, et al. Obesity and mortality among patients diagnosed with COVID-19: results from an integrated health care organization. Ann Intern Med. 2020;173(10):773-81. https://doi.org/10.7326/M20-3742.

56. Anderson MR, Geleris J, Anderson DR, Zucker J, Nobel YR, Freedberg D, et al. Body mass index and risk for intubation or death in SARS-CoV-2 infection: a retrospective cohort study. Ann Intern Med. 2020;173(10):78290. https://doi.org/10.7326/M20-3214.

57. Reilev M, Kristensen KB, Pottegard A, Lund LC, Hallas J, Ernst MT, et al. Characteristics and predictors of hospitalization and death in the first 11 122 cases with a positive RT-PCR test for SARS-CoV-2 in Denmark: a nationwide cohort. Int J Epidemiol. 2020;49(5):1468-81. https://doi.org/10.1 093/ije/dyaa140.

58. Farrell TW, Francis $L$, Brown $T$, Ferrante $L E$, Widera $E$, Rhodes $R$, et al. Rationing limited healthcare resources in the COVID-19 era and beyond: ethical considerations regarding older adults. J Am Geriatr Soc. 2020;68(6): 1143-9. https://doi.org/10.1111/jgs.16539.

59. Farrell TW, Ferrante LE, Brown T, Francis L, Widera E, Rhodes R, et al. AGS position statement: resource allocation strategies and age-related considerations in the COVID-19 era and beyond. J Am Geriatr Soc. 2020; 68(6):1136-42. https://doi.org/10.1111/jgs. 16537.

60. 2020;Pages. https://www.va.gov/vetdata/docs/Quickfacts/NA_Utilization Profile_2017.pdf.

61. Schuttner L, Reddy A, Rosland AM, Nelson K, Wong ES. Association of the Implementation of the patient-centered medical home with quality of life in patients with multimorbidity. J Gen Intern Med. 2020;35(1):119-25. https://doi.org/10.1007/s1 1606-019-05429-1.

62. Quan H, Sundararajan V, Halfon P, Fong A, Burnand B, Luthi JC, et al. Coding algorithms for defining comorbidities in ICD-9-CM and ICD-10 administrative data. Med Care. 2005;43(11):1130-9. https://doi.org/10.1097/ 01.mlr.0000182534.19832.83.

63. Fine J, Gray R. A proportional hazards model for the subdistribution of a competing risk. J Am Stat Assoc. 1999;94(446):496-509. https://doi.org/10.1 080/01621459.1999.10474144.

64. CDC;Pages. https://www.cdc.gov/vaccines/hcp/acip-recs/vacc-specific/ covid-19/evidence-table-phase-1b-1c.html.

65. Russo AG, Decarli A, Valsecchi MG. Strategy to identify priority groups for COVID-19 vaccination: a population based cohort study. Vaccine. 2021; 39(18):2517-25. https://doi.org/10.1016/j.vaccine.2021.03.076.

66. Ioannou GN, Green P, Fan VS, Dominitz JA, O'Hare AM, Backus LI, et al. Development of COVIDVax model to estimate the risk of SARS-CoV-2- related death among 7.6 Million US Veterans for use in vaccination prioritization. JAMA Netw Open. 2021:4(4):e214347.

67. King JT Jr, Yoon JS, Rentsch CT, Tate JP, Park LS, Kidwai-Khan F, et al. Development and validation of a 30-day mortality index based on preexisting medical administrative data from 13,323 COVID-19 patients: the veterans health administration COVID-19 (VACO) index. PLoS One. 2020; 15(11):e0241825. https://doi.org/10.1371/journal.pone.0241825.

68. Lee SJ, Go AS, Lindquist K, Bertenthal D, Covinsky KE. Chronic conditions and mortality among the oldest old. Am J Public Health. 2008;98(7):120914. https://doi.org/10.2105/AJPH.2007.130955.

69. Ben-Ezra M, Shmotkin D. Predictors of mortality in the old-old in Israel: the cross-sectional and longitudinal aging study. J Am Geriatr Soc. 2006;54(6): 906-11. https://doi.org/10.1111/j.1532-5415.2006.00741.x.

70. Hagg S, Jylhava J, Wang Y, Xu H, Metzner C, Annetorp M, et al. Age, frailty, and comorbidity as prognostic factors for short-term outcomes in patients with coronavirus disease 2019 in geriatric care. J Am Med Dir Assoc. 2020; 21(11):1555-9 e2. https://doi.org/10.1016/j.jamda.2020.08.014.

71. Chatterjee A, Wu G, Primakov S, Oberije C, Woodruff H, Kubben P, et al. Can predicting COVID-19 mortality in a European cohort using only demographic and comorbidity data surpass age-based prediction: an externally validated study. PLoS One. 2021;16(4):e0249920. https://doi.org/1 0.1371/journal.pone.0249920.

72. Nickel CH, Rueegg M, Pargger H, Bingisser R. Age, comorbidity, frailty status: effects on disposition and resource allocation during the COVID-19 pandemic. Swiss Med Wkly. 2020;150:w20269.

\section{Publisher's Note}

Springer Nature remains neutral with regard to jurisdictional claims in published maps and institutional affiliations.
Ready to submit your research? Choose BMC and benefit from:

- fast, convenient online submission

- thorough peer review by experienced researchers in your field

- rapid publication on acceptance

- support for research data, including large and complex data types

- gold Open Access which fosters wider collaboration and increased citations

- maximum visibility for your research: over $100 \mathrm{M}$ website views per year

At BMC, research is always in progress.

Learn more biomedcentral.com/submissions 